\title{
Analysis of the uniqueness of the combustion process of the Perkins 1104D-E44TA engine in dual-fuel operation powered by natural gas and diesel fuel
}

The paper presents the results of the research on the uniqueness of the combustion process in the Perkins 1104D-E44TA engine already equipped with a Common Rail injection system, and then adapted on an engine test stand to dual-fuel operation. The result of the combustion process is an indicator diagram. The combustion process in the cylinder of the tested engine was evaluated by determining the uniqueness indicators of subsequent operating cycles, such as: the uniqueness indicator for the maximum pressure of the operating cycle, the uniqueness indicator for the mean indicated pressure, the uniqueness indicator for the indicated diagram and the uniqueness indicator for the partial indicator diagram. The conducted tests and the analysis of the results showed the impact of dual-fuel power supply of the tested engine on the combustion process, as compared to supplying the engine only with diesel fuel, for which it has been optimized.

Key words: dual-fuel, natural gas, combustion process, indicator diagram, uniqueness of combustion process

\section{Introduction}

Fuels for compression-ignition combustion reciprocating engines must have high atomization, evaporation and air mixing capability, so as to ensure easy engine start-up as well as long service life and reliability. The conventional fuels used to power these engines are diesel fuels obtained from crude oil in the process of its distillation and in the process of secondary processing of heavy distillation residues. Diesel fuels are a mixture of many different hydrocarbons with different properties and structure of molecules, containing from 14 to 20 carbon atoms in a molecule, boiling at a temperature from $150^{\circ} \mathrm{C}$ to $380^{\circ} \mathrm{C}$ [1]. Its density at a temperature of $15^{\circ} \mathrm{C}$ is approximately $817-856 \mathrm{~kg} / \mathrm{m}^{3}$. Diesel fuels include the following hydrocarbons: linear paraffinic, branched isoparaffinic as well as naphthenic and aromatic with a ring structure. The number of individual hydrocarbon groups in diesel fuel determines its physicochemical properties affecting the efficiency of engine operation and the toxicity of exhaust fumes. In the elemental composition, diesel fuels contain about $86 \%$ of carbon and $14 \%$ of hydrogen $[23,24]$. The properties of modern diesel fuels used to power compression-ignition engines are well known, defined in detail and adapted to engine requirements. They are mainly characterized by good compression-ignition properties. They have a high calorific value per unit of mass as well as per unit of volume. Diesel fuels are relatively easy to store, transport and use as a fuel for combustion engines. The properties of diesel fuels change as needed, by modifying their hydrocarbon composition and introducing various additives.

Natural gas is an interesting alternative to power reciprocating combustion engines. It presents smaller risk to the environment compared to crude oil or coal. It is a fuel which occurs in large quantities and is characterized by favorable properties in terms of possibilities to power combustion engines [3, 21, 28]. First and foremost, by a simple chemical structure, which determines fast and complete combustion, low content of toxic compounds and solids, as well as a smaller quantity of carbon dioxide in exhaust fumes. It consists mainly of one, the simplest carbonhydrogen compound, methane. Its content in natural gas may be $85-99 \%$ [5]. Natural gas also includes other hydrocarbons such as ethane, propane, butane, isobutane, hexane, heptane, octane, pentane, isopentane. It may also contain impurities such as carbon dioxide, nitrogen, hydrogen sulphide, helium and small amounts of water vapor [2]. Natural gas is lighter than air. In the case of tank leaks, it quickly rises up to higher atmospheric layers. It forms explosive mixtures with air. The autoignition temperature of compressed natural gas can range from $480^{\circ} \mathrm{C}$ to approximately $630^{\circ} \mathrm{C}$ [11]. Under normal conditions, the density of natural gas vapor is $0.72-0.76 \mathrm{~kg} / \mathrm{m}^{3}$ [8]. The properties of natural gas are largely determined by the properties of methane, which is its main component. The boiling point of methane is $-161.0^{\circ} \mathrm{C}$ and the melting point is $-182.0^{\circ} \mathrm{C}$ [9]. Its autoignition temperature is $595^{\circ} \mathrm{C}$ [10]. It has a high octane number of about 130 , which means that it is resistant to detonation.

The properties of diesel fuel and natural gas presented above are significantly different. They make natural gas easier to use for powering spark-ignition engines. According to $[26,27]$, the autoignition temperature of natural gas can be $650^{\circ} \mathrm{C}$ and for diesel fuel $250^{\circ} \mathrm{C}$. Diesel fuels have the ability of autoignition at the level of the cetane number of 45-55, whereas natural gas is resistant to detonation described by the octane number at the level of 120-130 [12]. This makes it more difficult to use natural gas in compression-ignition engines. The natural gas/air mixture compressed in the cylinder will not self-ignite. An ignition source is required to initiate the combustion of a natural gas/air mixture. In addition, natural gas burns slower than liquid petroleum fuels for supplying high-speed combustion engines.

The calorific value per unit of mass for natural gas is greater than the calorific value of diesel fuel [4, 28, 29]. However, the density of natural gas at ambient conditions is, of course, much lower than that of diesel fuel. Thus, the calorific value of the gaseous fuel per volume unit at ambi- 
ent conditions is smaller than of diesel fuel. In order to increase the energy density of natural gas, it is necessary to compress it to high pressures (about $20 \mathrm{MPa}$ ) or to condense it at a temperature of about $-162^{\circ} \mathrm{C}$ and ambient pressure. Compression or condensation of natural gas is technologically and technically possible, but also causes additional problems in terms of transport, storage and use for powering the engines.

There are two options of the use of natural gas for powering compression-ignition engines. The first is the introduction of significant changes in the engine structure, i.e. a reduction in the compression ratio and the introduction of the ignition system. In fact, a compression-ignition engine becomes a spark-ignition engine and can no longer be powered by diesel fuel. The second option is the use of dualfuel supply [13, 14, 22, 25]. This means that two fuels can be burned simultaneously in a cylinder of a dual-fuel engine: natural gas and diesel fuel. Diesel fuel, injected at the end of the compression process, is the source of ignition of the natural gas. This approach allows the engine to be powered by two fuels simultaneously or by diesel fuel only. The technology of dual-fuel powering of compression-ignition engines by natural gas and diesel fuel is still being developed. The conducted research concerns, among others, the processes of fuel-air mixture formation and combustion while simultaneously powering the engine with natural gas and diesel fuel.

\section{Object of the study}

The object of the study was a four-cylinder compression-ignition engine Perkins 1104D-E44TA equipped with a Common Rail injection system with direct fuel injection and electromagnetically controlled injectors. It meets the Tier 3 emission standard for engines with non-road applications [19]. It is equipped with a forced induction with a turbocharger controlled by a blow off valve connected to the solenoid valve controlled by an electronic unit controlling the engine operation. On the basis of information provided by the sensors determining the engine operating conditions, this unit calculates the injected fuel dose, controlling the value of pressure in the fuel tank and the time of injection as well as charging pressure. The basic technical data of the tested engine are presented in Table 1.

Table 1. Basic technical data of the Perkins 1104D-E44TA diesel engine

\begin{tabular}{|l|c|c|}
\hline Parameter & Unit & Value \\
\hline Cylinder arrangement & - & straight \\
\hline No of cylinders & - & 4 \\
\hline Injection type & - & direct \\
\hline Type of fuel system & - & Common Rail \\
\hline Max. engine power & $\mathrm{kW}$ & 96,5 \\
\hline Engine speed at maximum power & $\mathrm{rpm}$ & 2200 \\
\hline Max. torque & $\mathrm{Nm}$ & 516,0 \\
\hline Engine speed at max. torque & $\mathrm{rpm}$ & 1400 \\
\hline Engine cubic capacity & $\mathrm{m}^{3}$ & $4.4 \cdot 10^{-3}$ \\
\hline Cylinder diameter & $\mathrm{mm}$ & 105 \\
\hline Piston stroke & $\mathrm{mm}$ & 127 \\
\hline Compression ratio & - & 16.2 \\
\hline Air supply system & - & turbocharger, intercooler \\
\hline
\end{tabular}

Perkins 1104D-E44TA engine, located at the engine test stand in the Heat Engines Laboratory at the Kielce University of Technology, has been adapted to dual-fuel operation using the compressed natural gas CNG and diesel fuel ON. This engine is equipped with a CNG powering system with an electronic control unit of the OSCAR-N DIESEL system [7]. The flow chart of the Perkins 1104D-E44TA engine powering system by CNG of the OSCAR-N DIESEL system is shown in Figure 1. Gaseous fuel is delivered to the intake system between the turbocharger and the intercooler. Natural gas is fed by means of four injectors mounted on a common rail. Injectors supply gas fuel through flexible hoses to the hose, where the air from the turbocharger flows to the cooler. The mixture of gaseous fuel and air after passing through the cooler is fed to the engine cylinders. It is compressed in the engine cylinders. At the end of the compression process, a reduced amount of diesel fuel is injected into the cylinder, which then ignites itself and in the cylinder. The amount of gaseous fuel supplied to the engine intake system shall be determined by the controller of the system for powering the engine with this fuel. This depends on the operating conditions of the engine. The amount of natural gas supplied to the cylinder must not exceed the amount causing detonation and exceeding the permissible temperatures. This means that at higher loads, the dose of natural gas is reduced and the dose of diesel fuel is increased. In the absence of gaseous fuel, the engine is conventionally powered by diesel fuel.

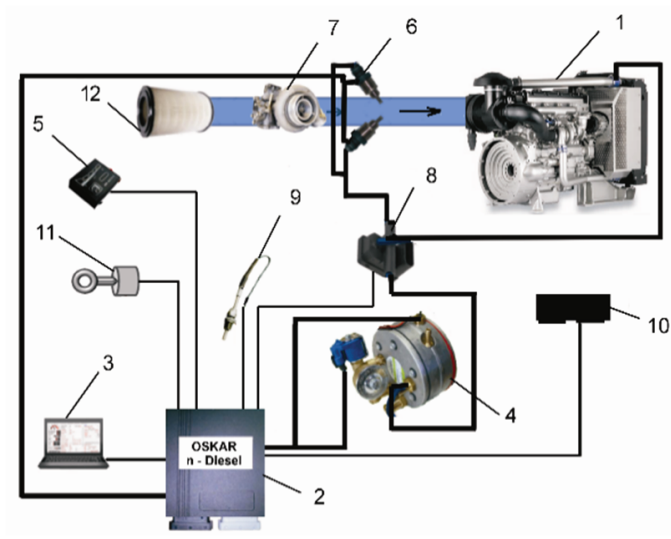

Fig. 1. The flow chart of the natural gas fuelling system OSCAR-N DIESEL: 1 - Perkins 1104D-E44TA engine, 2 - controller of the engine gas fuelling system, 3 - computer, 4 - reducer, 5 - gas system switch, 6 - gas injectors, 7 - turbocharger, 8 - gas pressure regulator, 9 - temperature sensor, $10-$ emulator, 11 - ignition switch, 12 - air filter

\section{Engine test stand}

The tests were carried out on an engine test stand located in the Heat Engines Laboratory at the Kielce University of Technology. Perkins 1104D-E44TA engine being tested at this stand is connected with an eddy current brake, which enables the engine to operate under various load and crankshaft speed conditions. The change of the engine test stand's operational parameters is carried out by means of a control module located in the control room of the test stand. The measurement of the mass consumption of diesel fuel in the tested engine is carried out using the fuel gauge manufactured by Automex. Mass consumption of natural starts the process of combustion of the gas fuel accumulated 
gas is measured at the test stand using the Coriolis flow meter by Emerson. An accurate measurement of the mass of air supplied to the cylinders is carried out using an $\mathrm{ABB}$ flow meter. The diagram of the engine test stand on which the tests were performed is shown in Fig. 2.

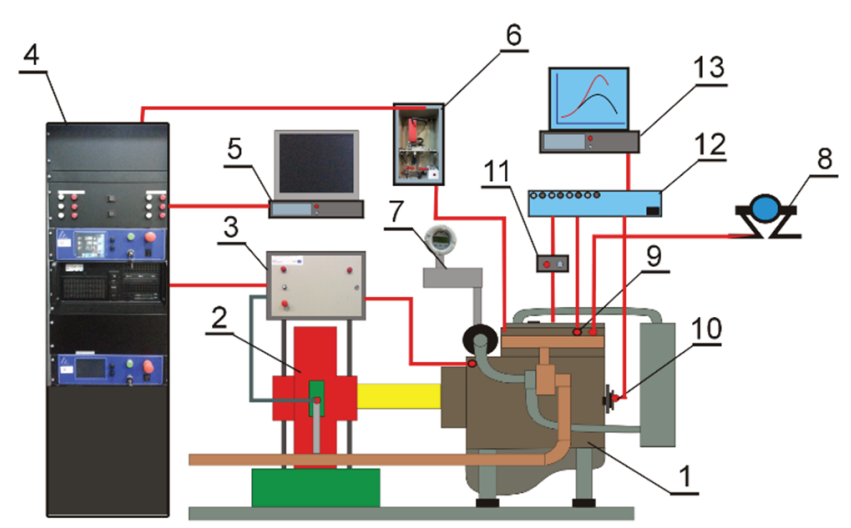

Fig. 2. Test stand elements: 1- Perkins 1104D - E44TA engine, 2 - Automex AMX 200/6000 brake, 3 - measurement module, 4 - measurement cabinet with stand control system, 5 - computer to control station parameters and archive test results, 6 - Automex ATMX2040 mass fuel dosimeter, 7 - ABB mass air flow meter, 8 - Coriolis flow meter for measurement of CNG consumption, 9 - sensor of the pressure in the engine cylinder, 10 - engine crank angle encoder AVL 365C, 11 - converter for measuring the current controlling the operation of the injector LA25NP, 12 - AVL IndiSmart 612 system for indicating fast-changing quantities, 13 - computer for archiving fast-changing quantities

The tests of the working medium pressure in the Perkins 1104D - E44TA engine cylinder were carried out using the AVL IndySmart 612 measuring system. It consisted of the following elements:

- AVL IndiSmart 612 data acquisition system,

- piezoelectric pressure sensor in the AVL GH13P/AG04 engine cylinder,

- optical encoder of an engine crank angle AVL 365C.

The piezoelectric sensor enables the continuous measurement of the pressure in the engine cylinder. The analogue signal from the sensor is sampled at high frequency. The AVL 365C photoelectric encoder used in the system generates 720 electrical impulses per revolution. This allows the pressure to be measured in increments of $0.5^{\circ}$ of the crank angle. The measurement system enables the multiplication of this signal, which allows to increase the resolution of the measurement to $0.1^{\circ}$ of the crank angle. AVL Indicom Mobile 2012 is used to operate the engine cylinder pressure measuring system. It allows, among other things, to record pressure for subsequent operation cycles and to draw up mean indicator diagrams. It also enables the analysis of the combustion process based on the heat released during this process. The system for measuring the fastchanging quantities of the tested engine has been additionally equipped with a system for measuring the current controlling the operation of the injector. This system was connected in series to the line controlling the operation of the injector of this cylinder, in which the pressure was recorded. It made it possible to record the profile of the current controlling the operation of the injector as a function of the crank angle. The flow chart of the fast-changing quantity measurement system used during the tests is shown in Fig. 3.

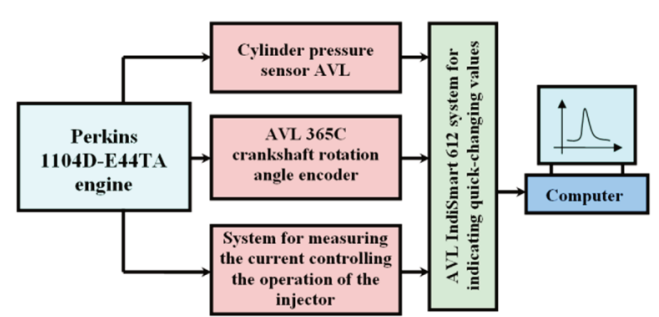

Fig. 3. The flow chart of the measurement system of fast-changing quantities of Perkins 1104D-E44TA engine used for testing

\section{Indicator diagrams for Perkins 1104D-E44TA engine in dual-fuel operation}

Tests of Perkins 1104D-E44TA engine running on compressed natural gas and diesel $\mathrm{CNG}+$ Diesel in dualfuel operation and, for comparison, when powered by diesel fuel only, were conducted when it was operating according to the external speed characteristics and the load characteristics for crankshaft speed $n=1800 \mathrm{rpm}$. Using the AVL IndiSmart 612 system for measuring fast-changing quantities, the pressure waveform in the cylinder of the engine under test were recorded for subsequent fifty operating cycles under steady state conditions. The measurements of the pressure in the cylinder were carried out with a resolution of $0.1^{\circ}$ of the crank angle. Diagrams constituting Figure 4 show example results of pressure measurements in the engine cylinder as a function of the crank angle for subsequent fifty operating cycles of the Perkins 1104D-E44TA engine in dual-fuel operation and powered by diesel fuel only. The diagrams show that in the case of an engine powered by $\mathrm{CNG}$ and diesel fuel, the spread of the maximum combustion pressures is significantly greater than the spread of these values obtained in an engine powered by diesel fuel only. It should be noted that the diagrams presented were developed at low engine load, where the share of natural gas in total fuel consumption is high. The sets of indicator diagrams determined under the steady state operating conditions, while powering the tested engine with a specific fuel, were used to calculate the uniqueness of the combustion process. Figure 5 shows a comparison of the pressure waveforms during the combustion process in the Perkins 1104D-E44TA engine cylinder operating according to external speed characteristics for selected crankshaft speeds $\mathrm{n}=1400,1800$ and $2200 \mathrm{rpm}$, in dual-fuel operation $\mathrm{CNG}+$ Diesel and powered by diesel fuel only. For the two different powering methods tested, slight differences in the pressure waveforms were obtained. Figure 6 shows a comparison of the pressure waveforms during the combustion process in the Perkins 1104D-E44TA engine cylinder operating according to the load characteristics for crankshaft speed $\mathrm{n}=1800 \mathrm{rpm}$, with selected loads of the engine $\mathrm{T}=$ $=20,200$ and $450 \mathrm{Nm}$, in dual-fuel CNG + Diesel operation and powered by diesel fuel only. In this case, greater differences in pressure waveforms during the combustion process at lower loads can be noted. These differences become smaller as the load increases. This is due to the fact that as the load increases, the energy share of natural gas in the total amount of energy supplied to the engine cylinders significantly decreases. The energy share of natural gas in the total energy supplied to the engine cylinders for the tests performed is shown in Fig. 7. 

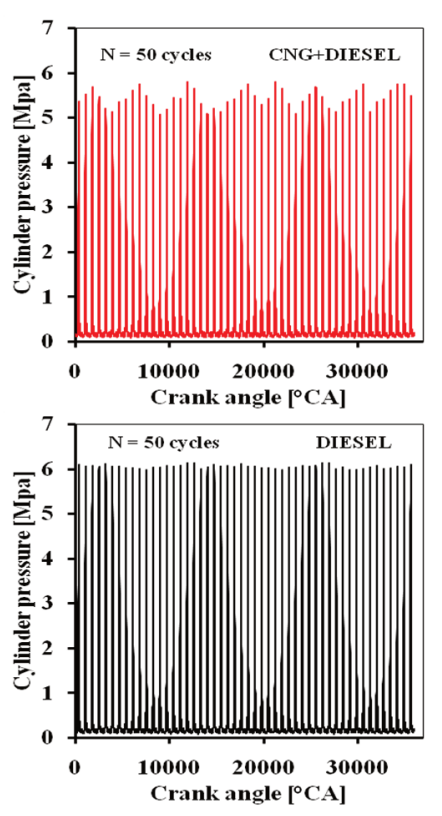

Fig. 4. Example sets of indicator diagrams determined under steady state conditions for subsequent operating cycles of Perkins 1104D-E44TA engine in dual-fuel CNG + Diesel operation and powered by diesel fuel only, operating according to the load characteristics for crankshaft speed $\mathrm{n}=1800 \mathrm{rpm}$ and load $\mathrm{T}=20 \mathrm{Nm}$
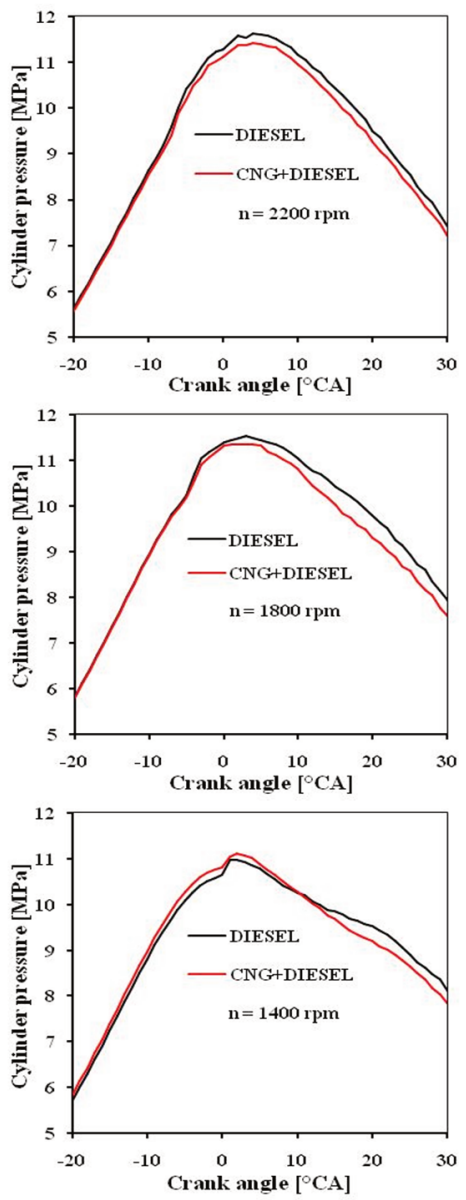

Fig. 5. Comparison of the pressure waveforms during the combustion process in the Perkins 1104D-E44TA engine cylinder operating according to external speed characteristics for selected crankshaft speeds $n=1400$, 1800 and $2200 \mathrm{rpm}$, in dual-fuel CNG + Diesel operation and powered by diesel fuel only
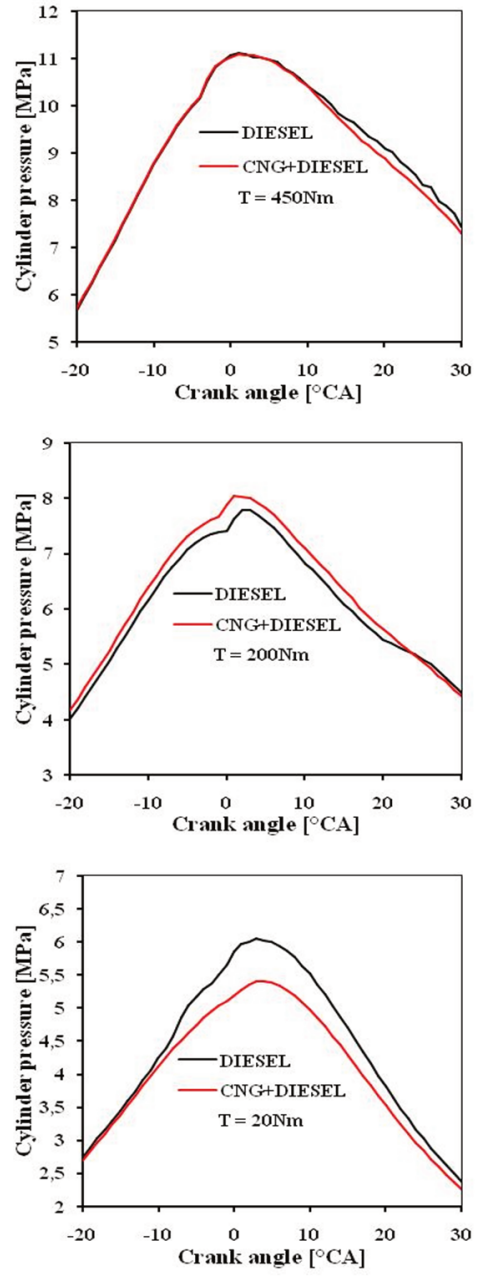

Fig. 6. Comparison of the pressure waveforms during the combustion process in the Perkins 1104D-E44TA engine cylinder running according to the load characteristics for crankshaft speed $\mathrm{n}=1800 \mathrm{rpm}$, with selected loads of the engine $\mathrm{T}=20,200$ and $450 \mathrm{Nm}$, in dual-fuel CNG + Diesel operation and powered by diesel fuel only
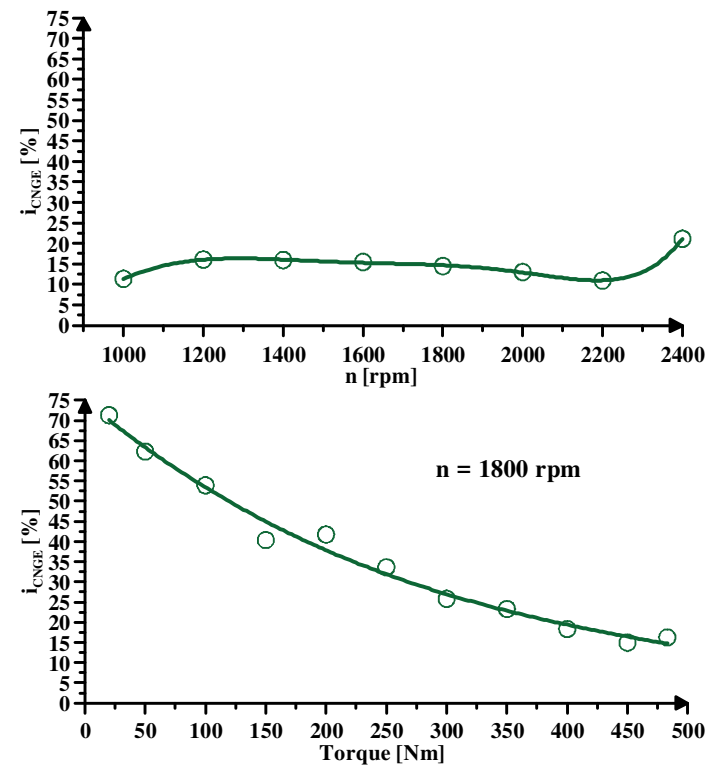

Fig. 7. The energy share of natural gas in the total energy input to the cylinders of the Perkins 1104D-E44TA engine running in dual-fuel CNG + Diesel operation and according to external speed characteristics and load characteristics for crankshaft speed $\mathrm{n}=1800 \mathrm{rpm}$ 


\section{Combustion process uniqueness indicators}

The result of the processes taking place in a reciprocating combustion engine is an indicator diagram. It makes it possible to determine the basic indicators of engine operation and combustion process parameters. With subsequent indicator diagrams of the operating engine, it is possible to assess the correctness of the combustion process. The aim is to ensure that the indicator diagrams of the engine running under steady operating conditions are the same. In fact, these diagrams vary. Each subsequent pressure waveform in the cylinder is different from the previous one. This is the result of the variability of the processes occurring in the engine: air supply process, fuel injection process, fuelair mixing process, ignition initiation or autoignition process, environmental condition variability. An important factor affecting the course of subsequent operating cycles in the engine cylinder during its tests on the test stand is the ability to ensure stable engine operation parameters [20]: crankshaft speed, torque curve, constant temperatures and pressures of: collector air, engine lubricating oil and cooling liquid. The lack of repeatability of these processes occurring in the engine and the variability of the engine operating conditions causes that the subsequent cycles of its operation differ. This may affect the values of the engine's performance indicators, including engine noise and exhaust fumes composition. In addition, the problem of the uniqueness of subsequent indicator diagrams should be taken into account when analyzing them. A single recorded pressure waveform may not be representative of the engine and the indicators determined on its basis. Therefore, usually for the analysis of the indicator diagram, a mean diagram of several dozen operating cycles measured under steady conditions of the engine operation is prepared. It may then be assumed that such an indicator diagram is representative of an engine operating under the specified conditions.

Uniqueness is a statistical parameter used to characterize the variability of the data set obtained from measurements. The uniqueness of the combustion process can be assessed by determining the uniqueness of the parameters characterizing this process $[15-18,20]$. Classical indicators of the uniqueness of the combustion and fuel injection process have been discussed, among others, by Heywood [6]. The combustion process is analyzed on the basis of indicator diagrams and parameters determined on its basis. The uniqueness or, in other words, variability of these parameters shall be determined by dividing the standard deviation of a given parameter by its mean value in the set of results:

$$
\mathrm{X}_{\mathrm{Y}}=\frac{\sigma_{\mathrm{Y}}}{\overline{\mathrm{Y}}}
$$

where: $\sigma_{\mathrm{Y}}$ - standard deviation of parameter $\mathrm{Y}, \overline{\mathrm{Y}}$ - average value of the parameter under consideration.

The paper includes the analysis of the uniqueness for the combustion process of Perkins 1104D-E44TA engine running on compressed natural gas and diesel fuel in dualfuel operation and on diesel fuel only. The values of four uniqueness indicators for subsequent engine operating cycles were determined: the uniqueness indicator for the maximum combustion pressure of the operating cycle, the uniqueness indicator for the mean indicated pressure, the uniqueness indicator for the indicator diagram and the uniqueness indicator for the partial indicator diagram.

The values of the uniqueness indicator for the maximum combustion pressure of the operating cycle were calculated with the equation:

$$
\mathrm{X}_{\mathrm{p}_{\max }}=\frac{\sigma_{\mathrm{p}_{\max }}}{\overline{\mathrm{p}}_{\max }}=\frac{\sqrt{\frac{1}{\mathrm{~N}} \sum_{\mathrm{i}=1}^{\mathrm{N}}\left(\mathrm{p}_{\max , \mathrm{i}}-\overline{\mathrm{p}}_{\max }\right)^{2}}}{\overline{\mathrm{p}}_{\max }}
$$

where: $p_{\text {max }, i}-$ maximum combustion pressure of the $i$-th operating cycle of the engine, $\sigma_{\mathrm{p}_{\max }}-$ standard deviation of the maximum combustion pressure, $\overline{\mathrm{p}}_{\max }$ - average maximum combustion process pressure calculated from $\mathrm{N}$ engine's subsequent operating cycles, $\mathrm{N}$ - number of subsequent engine operating cycles recorded.

The indicator of the uniqueness of the mean indicated pressure has been calculated using the equation:

$$
\mathrm{X}_{\mathrm{p}_{\mathrm{i}}}=\frac{\sigma_{\mathrm{p}_{\mathrm{i}}}}{\overline{\mathrm{p}}_{\mathrm{i}}}=\frac{\sqrt{\frac{1}{\mathrm{~N}} \sum_{\mathrm{i}=1}^{\mathrm{N}}\left(\mathrm{p}_{\mathrm{i}, \mathrm{i}}-\overline{\mathrm{p}}_{\mathrm{i}}\right)^{2}}}{\overline{\mathrm{p}}_{\mathrm{i}}}
$$

where: $\sigma_{p_{i}}-$ standard deviation of the mean indicated pressure value, $\bar{p}_{i}$ - average value of the mean indicated pressure from the subsequent $\mathrm{N}$ operating cycles of the engine, $p_{i, i}-$ average indicated pressure of the $i$-th cycle.

The uniqueness indicator for the indicator diagram was determined from the following formula:

$$
X_{S}=\frac{\sigma_{S}}{\bar{S}}=\frac{\sqrt{\frac{1}{N} \sum_{i=1}^{N}\left(S_{i}-\bar{S}\right)^{2}}}{\bar{S}}
$$

where: $\sigma_{S}-$ standard deviation of the area under the opened indicator diagram, $\overline{\mathrm{S}}-$ mean value of the area under the opened indicator diagram calculated for subsequent $\mathrm{N}$ operating cycles of the engine, $S_{i}-$ area under the $i$-th opened indicator diagram.

The area under the opened indicator diagram was calculated from the formula:

$$
S=\int_{\alpha_{p}}^{\alpha_{k}} p d \alpha
$$

where: $\alpha_{p}, \alpha_{k}$-values of the crank angle corresponding to the first and last point on the analyzed indicator diagram.

The uniqueness indicator for the partial indicator diagram has been calculated using the equation:

$$
\mathrm{X}_{\mathrm{S}_{\mathrm{C}}}=\frac{\sigma_{\mathrm{S}_{\mathrm{C}}}}{\overline{\mathrm{S}}_{\mathrm{C}}}=\frac{\sqrt{\frac{1}{\mathrm{~N}} \sum_{\mathrm{i}=1}^{\mathrm{N}}\left(\mathrm{S}_{\mathrm{C}, \mathrm{i}}-\overline{\mathrm{S}}_{\mathrm{C}}\right)^{2}}}{\overline{\mathrm{S}}_{\mathrm{C}}}
$$

where: $\sigma_{S_{C}}-$ standard deviation of the area under the curve of the opened indicator diagram from the closing of inlet valves to the opening of outlet valves, $\overline{\mathrm{S}}_{\mathrm{C}}-$ mean 
value of the area for the following $\mathrm{N}$ diagrams calculated under the opened indicator curve from the closing of inlet valves to the opening of outlet valves, $S_{C, i}-$ value of the area under the curve of the i-th opened indicator diagram from the closing of inlet valves to the opening of outlet valves.

The surface area under the curve of the partial indicator diagram limited by the crank angle at which the inlet valves close and the crank angle at which the outlet valves begin to open is calculated from the formula:

$$
\mathrm{S}_{\mathrm{C}}=\int_{\alpha_{\mathrm{zd}}}^{\alpha_{\mathrm{ow}}} \mathrm{pd} \alpha
$$

$\alpha_{\mathrm{zd}}, \alpha_{\mathrm{ow}}-$ values of the crank angle corresponding respectively to the closing of inlet valves and opening of outlet valves.

\section{Analysis of the uniqueness indicators \\ for the combustion process of the Perkins 1104D-E44TA engine in dual-fuel operation running on natural gas and diesel fuel}

The diagrams below present the comparison of the uniqueness indicators of the combustion process of Perkins 1104D-E44TA engine running on compressed natural gas and diesel fuel CNG + Diesel in dual-fuel operation and, for comparison, on diesel fuel only. The results of the calculation of the uniqueness indicator for the maximum combustion pressure of the operating cycle of the tested engine operating according to the external speed characteristics are shown in Figure 8. They obtain similar values for engines in dual-fuel operation powered by $\mathrm{CNG}+$ Diesel fuel and by diesel fuel only. The obtained values of this indicator do not show an unambiguous correlation for the two methods of powering. It should be noted, however, that the energy share of natural gas in the total amount of energy supplied to the engine during its operation according to its external speed characteristics is practically below $20 \%$. As a result, there are no significant differences in the combustion process on the indicator diagram. The values of the uniqueness indicator for the maximum combustion pressure of the operating cycle of the Perkins 1104D-E44TA engine running according to the load characteristics are shown in Figure 9. For loads of 20, 50 and $100 \mathrm{Nm}$, higher values of this ratio were obtained in the case of dual-fuel supply. However, they decrease significantly as the load increases. For loads above $100 \mathrm{Nm}$, similar values of the uniqueness indicator for the maximum combustion pressure of the cycle of the tested engine in dual-fuel operation and running on diesel fuel were obtained. As the load increases, the energy share of natural gas in the total amount of fuel supplied to the cylinders decreases.

Figures 10 and 11 present the values of uniqueness indicators of the mean indicated pressure of the Perkins 1104DE44TA engine, operating according to external speed characteristics and load characteristics for crankshaft speed $n=$ $1800 \mathrm{rpm}$, in dual-fuel operation powered by CNG + Diesel and by diesel fuel only. In the case of dual-fuel operation of the engine, greater values of the uniqueness indicator of the mean indicated pressure as compared to the engine running on diesel fuel were obtained. Definitely greater values of this indicator were obtained for the smallest loads $(20 \mathrm{Nm}$ and $50 \mathrm{Nm}$ ) at engine operation according to the load characteristics. Under these engine operating conditions, the energy share of natural gas in dual-fuel operation was $71 \%$ and $62 \%$, respectively. With an increase in engine load and a decreasing share of natural gas from about $54 \%$ to about $16 \%$, the differences in the analyzed indicator for the two methods of powering are not so significant.

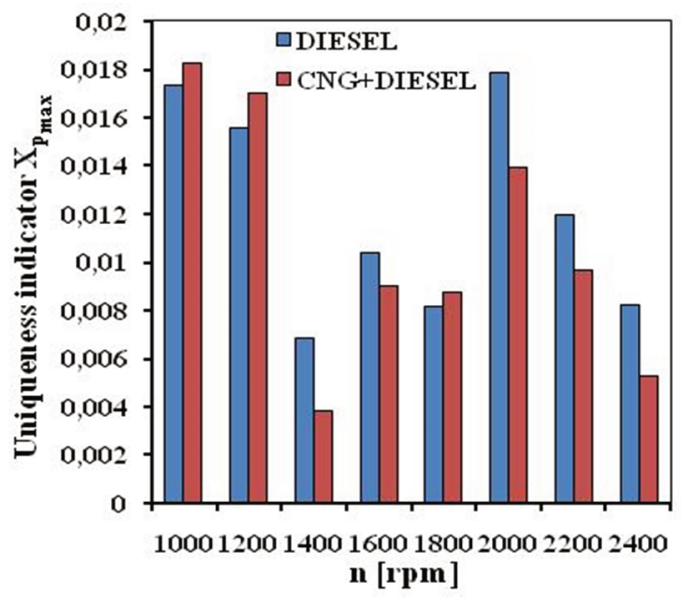

Fig. 8. Comparison of the value of the uniqueness indicator for the maximum pressure of the combustion process of the operating cycle of the Perkins 1104D-E44TA engine operating according to external speed characteristics, in dual-fuel operation, powered by CNG + Diesel and by diesel fuel only

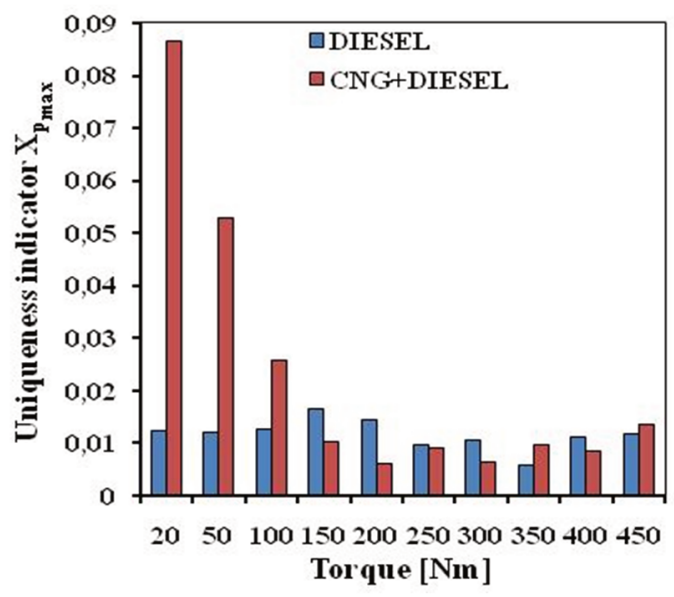

Fig. 9. Comparison of the value of the uniqueness indicator for the maximum pressure of the combustion process of the operation cycle in the Perkins 1104D-E44TA engine cylinder, running according to load characteristics for crankshaft speed $\mathrm{n}=1800 \mathrm{rpm}$, in dual-fuel operation powered by $\mathrm{CNG}+$ Diesel and by diesel fuel only

The values of the uniqueness indicator for the indicator diagram and the uniqueness indicator for the partial indicator diagram of the Perkins 1104D-E44TA engine in dualfuel operation powered by $\mathrm{CNG}+$ Diesel and diesel fuel only are shown in Figures 12 to 15. For a dual-fuel engine, both during operation according to external speed characteristics and load characteristics, higher values of the above-mentioned indicators were obtained. The greatest differences in the values of uniqueness indicators of the indicator diagram and partial indicator diagram for two methods of powering the tested engine were obtained at low engine loads. 


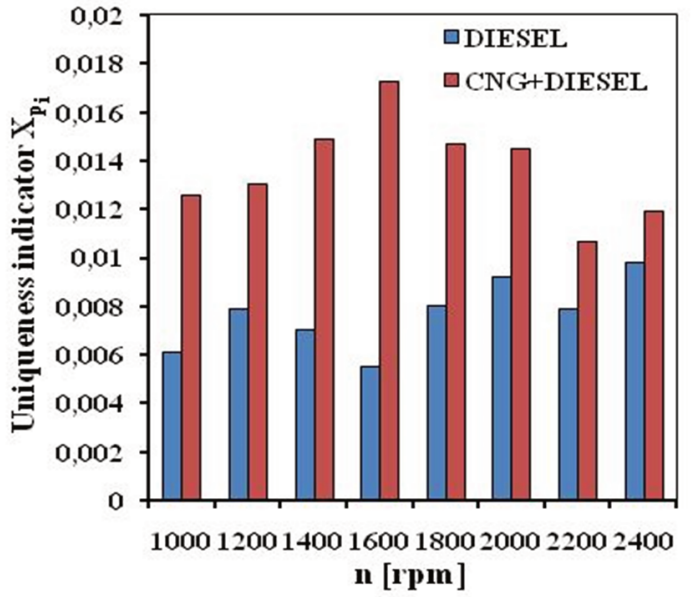

Fig. 10. Comparison of the value of the uniqueness indicator for the mean indicated pressure of the Perkins 1104D-E44TA engine operating according to external speed characteristics, in dual-fuel operation powered by CNG + Diesel and by diesel fuel only

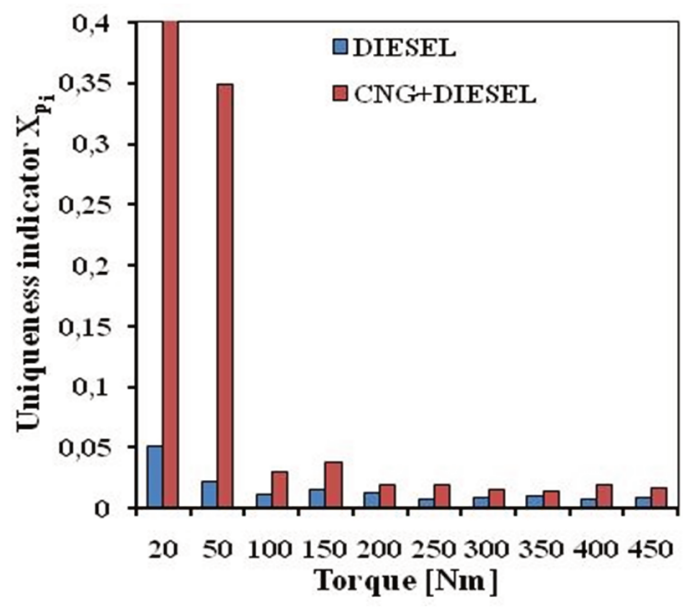

Fig. 11. Comparison of the value of the uniqueness indicator for the mean indicated pressure of the Perkins 1104D-E44TA engine, running according to load characteristics for crankshaft speed $n=1800 \mathrm{rpm}$, in dual-fuel operation powered by CNG + Diesel and by diesel fuel only

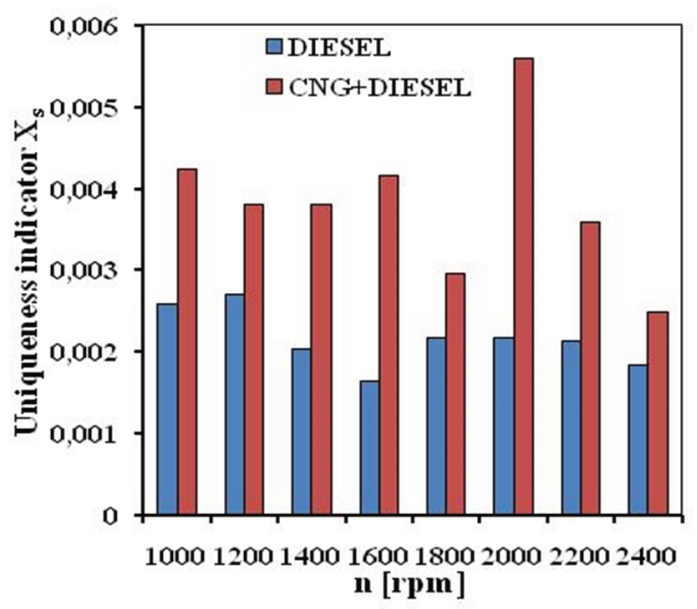

Fig. 12. Comparison of the value of the uniqueness indicator for the indicator diagram of the Perkins 1104D-E44TA engine operating according to external speed characteristics, in dual-fuel operation powered by $\mathrm{CNG}+$ Diesel and by diesel fuel only

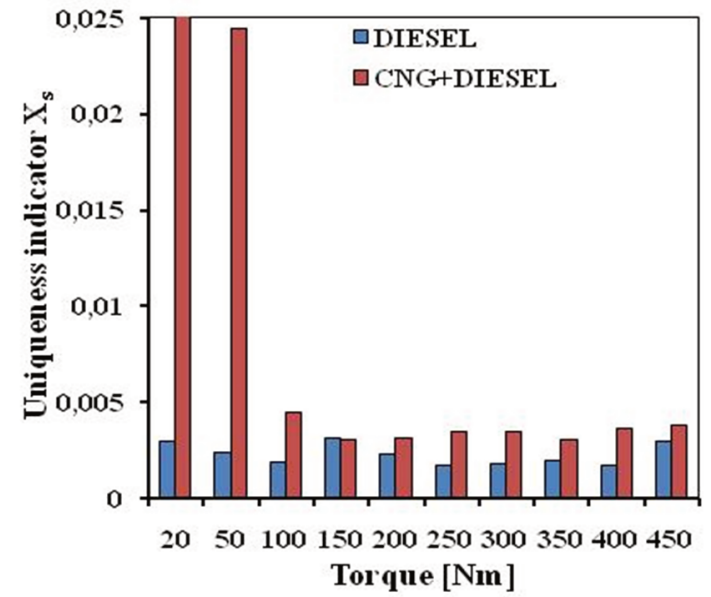

Fig. 13. Comparison of the value of the uniqueness indicator for the indicator diagram for the Perkins 1104D-E44TA engine, operating according to load characteristics for crankshaft speed $n=1800 \mathrm{rpm}$, in dual-fuel operation powered by CNG + Diesel and by diesel fuel only

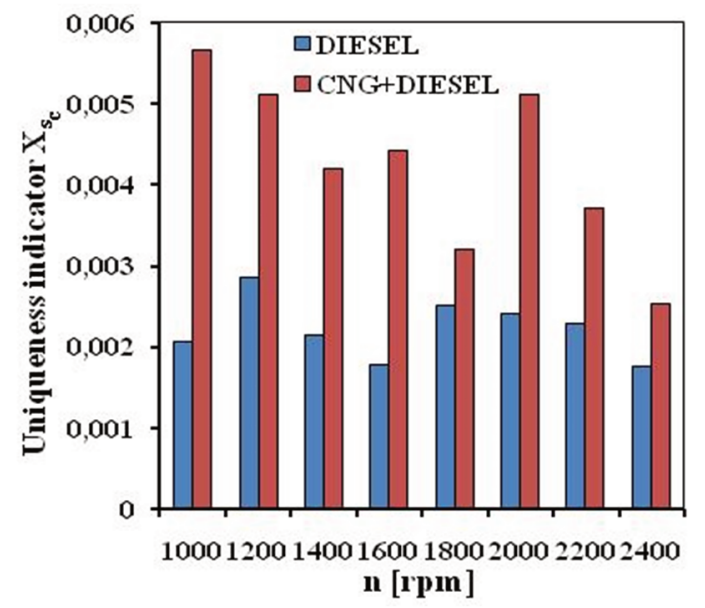

Fig. 14. Comparison of the value of the uniqueness indicator for the partial indicator diagram of the Perkins 1104D-E44TA engine operating according to external speed characteristics, in dual-fuel operation powered by $\mathrm{CNG}+$ Diesel and by diesel fuel only

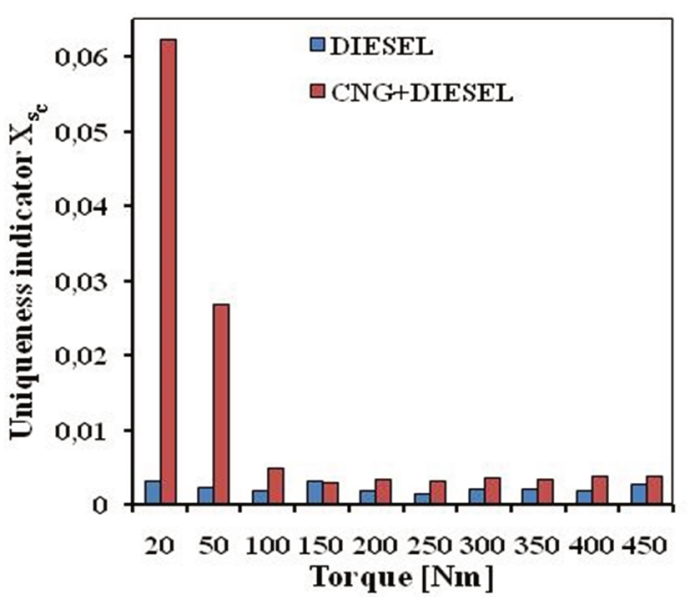

Fig. 15. Comparison of the value of the uniqueness indicator for the partial indicator diagram for the Perkins 1104D-E44TA engine, operating according to load characteristics for crankshaft speed $n=1800 \mathrm{rpm}$, in dual-fuel operation powered by CNG + Diesel and by diesel fuel only 


\section{Conclusion}

The research showed that when powering the Perkins 1104D-E44TA engine by both natural gas and diesel fuel, the values of uniqueness indicators: mean indicator pressure, indicator diagram and partial indicator diagram are greater than when powering the engine by diesel fuel. Significantly greater values of the above-mentioned indicators were obtained at the lowest loads of the engine operating according to the load characteristics. The obtained values of the uniqueness indicator for the maximum combustion pressure of the operating cycle of Perkins 1104D-E44TA engine for the smallest loads of the engine operating according to the load characteristics are also significantly greater when powering the engine by natural gas and diesel fuel. For the remaining measuring points, the values of this indicator do not differ significantly and are not clearly smaller or greater for one of the two methods of powering the tested engine. The results obtained are certainly influenced by significantly different physical and chemical properties of natural gas and diesel fuel, as well as different shares of natural gas in the total amount of fuel supplied to the engine cylinders. The share of natural gas in the total amount of fuel supplied to the engine cylinders could not be the same, due to the possibility of detonation under greater engine loads. With low engine loads and a high share of natural gas in a dual-fuel supply, this type of supply has a significant impact on the processes occurring in the engine cylinder. The uniqueness of the combustion process is clearly increasing. When the engine is running according to external speed characteristics and at high loads, the uniqueness for most of the indicators determined is greater in the case of dual-fuel supply. However, these differences between dual-fuel operation and powering by conventional fuels are not significant. According to the authors, further research should be carried out on the uniqueness of the combustion process in dual-fuel operation of the engine, with constant load and different shares of natural gas in the total amount of fuel supplied to the engine cylinders.

\section{Bibliography}

[1] BOCHEŃSKI, C.I. Biodiesel paliwa rolnicze. Wydawnictwo SGGW. Warszawa 2003.

[2] CHEN, H., HE, J., ZHONG, X. Engine combustion and emission fuelled with natural gas: A review. Journal of the Energy Institute. 2018, 1-14.

[3] CHO, H.M., HE, B.Q. Combustion and emission characteristics of a lean burn natural gas engine. International Journal of Automotive Technology. 2008, 9(4), 415-422, DOI: 10.1007/s12239-008-0050-5.

[4] GHAREHGHANI, A., HOSSEINI R., MIRSALIM, M. et al. An experimental study on reactivity controlled compression ignition engine fueled with biodiesel/natural gas. Energy. 2015, 89, 558-567, DOI: 10.1016/j.energy.2015.06.014.

[5] GRUDEN, D. Umweltschutz in der Automobilindustrie. Vieweg + Teubner-GWV Fachverlage GmbH, Wiesbaden 2008.

[6] HEYWOOD, J.B. Internal combustion engines fundamentals. Mc Graw Hill Co. N.Y. 1988.

[7] Instrukcja montażu i programowania systemu OSCAR-N DIESEL.

[8] Karta charakterystyki. Gaz ziemny ( $<200 \mathrm{kPa})$. Polskie Górnictwo Naftowe i Gazownictwo PGNiG.

[9] Karta charakterystyki. Metan. Messer 2016.

[10] Karta charakterystyki. Metan sprężony. Linde 2017.

[11] Karta charakterystyki substancji niebezpiecznej. Gaz ziemny w sieciach przesyłowych i dystrybucyjnych. Polskie Górnictwo Naftowe i Gazownictwo PGNiG. Warszawa 30.10 . 2010.

[12] KHAN, M.I., YASMIN, T., SHAKOOR, A. Technical overview of compressed natural gas (CNG) as a transportation fuel. Renewable and Sustainable Energy Reviews. 2015, 51, 785-797. DOI:10.1016/j.rser.2015.06.053.

[13] KURCZYŃSKI, D., ŁAGOWSKI, P., TOMYUK, V. Selected aspects of dual-fuelling of the Perkins 1104D-E44TA engine with natural gas and diesel fuel. Technical Transactions. 2018, 12, 173-178. DOI: 10.4467/2353737XCT.18.190.9678.

[14] KURCZYŃSKI, D., ŁAGOWSKI, P., WARIANEK, M. The impact of natural gas on the ecological safety of using Diesel engine. Published in: 2018 XI International ScienceTechnical Conference Automotive Safety. Conference Loca- tion: Casta. 18-20 April 2018. IEEE Xplore: 17823659. DOI:10.1109/AUTOSAFE. 2018.8373341.

[15] LEJDA, K., KURCZYŃSKI, D., ŁAGOWSKI, P. et al. The evaluation of the Fiat 0.9 Twin air engine powered by petrol and LPG gas work cycles uniqueness. Journal of KONES Powertrain and Transport. 2018, 25(3), 323-330.

[16] LONGWIC, R. Charakterystyka działania silnika o zapłonie samoczynnym w warunkach swobodnego rozpędzania. Wydawca Politechnika Lubelska. Lublin 2011.

[17] LOTKO, W. Niepowtarzalność opóźnienia samozapłonu paliwa w silniku o zapłonie samoczynnym. Archiwum Motoryzacji. 2008, 3-4, 195-209.

[18] LOTKO, W., GÓRSKI, K., TRELA, Z. et al. Wpływ parametrów paliwa na niepowtarzalność procesu spalania w silniku o zapłonie samoczynnym. Autobusy-Technika, Eksploatacja. Systemy Transportowe. 2018, 12, 508-513. DOI: 10.24136/atst.2018.442.

[19] Perkins, operation and maintenance manual, Perkins Engines Company Limited, 2012.

[20] PRZYBYŁA, G., POSTRZEDNIK, S. Niepowtarzalność cykli pracy silnika spalinowego przy jego wysokiej prędkości obrotowej oraz różnym obciążeniu. Czasopismo Techniczne M. 2008, 7-M, 151-159.

[21] REIF, K., DIETSCHE, K-H. Kraftfahrtechnisches Taschenbusch. Vieweg + Teubner Verlag. Wiesbaden 2011.

[22] SAHOO, B.B., SAHOO, N., SAHA, U.K. Effect of engine parameters and type of gaseous fuel on the performance of dual-fuel gas diesel engines - a critical review. Renewable and Sustainable Energy Reviews. 2009, 13, 1151-1184. DOI:10.1016/j.rser.2008.08.003.

[23] SZLACHTA, Z. Zasilanie silników wysokoprężnych paliwami rzepakowymi. Wydawnictwo Komunikacji $i$ Łaczności. Warszawa 2002.

[24] TARABET, L., LOUBAR, K., LOUNICI, M.S. et al. Experimental investigation of DI diesel engine operating with eucalyptus biodiesel/natural gas under dual fuel mode. Fuel. 2014, 133, 129-138. DOI: 10.1016/j.fuel.2014.05.008.

[25] THIRUVENGADAM, A., BESCH, M., PADMANABAN, V. et al. Natural gas vehicles in heavy-duty transportation - 
a review. Energy Policy. 2018, 122, 253-259. DOI:10.1016/ j.enpol.2018.07.052.

[26] WANG, Z., DU, G., WANG, D. et al. Combustion process decoupling of a diesel/natural gas dual-fuel engine at low loads. Fuel. 2018, 232, 550-561. DOI: 10.1016/j.fuel.2018. 05.152 .

[27] WANG, Z., ZHAO, Z., WANG, D. et al. Impact of pilot diesel ignition mode on combustion and emissions characteristics of a diesel/natural gas dual fuel heavy-duty engine. Fuel. 2016, 167, 248-256. DOI:10.1016/j.fuel.2015.11.077.

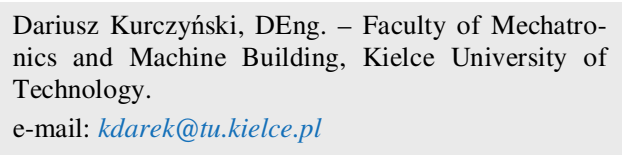

e-mail: kdarek@tu.kielce.pl

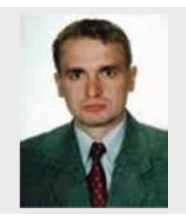

Piotr Łagowski, DEng. - Faculty of Mechatronics and Machine Building, Kielce University of Technology.

e-mail: p.lagowski@tu.kielce.pl 09.018.
Michał Warianek, MEng. - Faculty of Mechatronics and Machine Building, Kielce University of Technology.

e-mail:mwarianek@tu.kielce.pl
[28] WEI, L., GENG, P. A review on natural gas/diesel dual fuel combustion, emissions and performance. Fuel Processing Technology. 2016, 142, 264-278. DOI:10.1016/j.fuproc.2015.

[29] YANG, B., ZENG, K. Effects of natural gas injection timing and split pilot fuel injection strategy on the combustion performance and emissions in a dual-fuel engine fueled with diesel and natural gas. Energy Conversion and Management. 2018, 168, 162-169. DOI: 10.1016/j.enconman.2018.04.091.

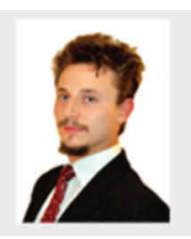

